\title{
Hemangiosarcoma in a Free-living Rufous-bellied Thrush (Turdus rufiventris)
}

\section{Samara Rosolem Lima', Thais Oliveira Morgado', Kalinne Stephanie Bezerra', Fabiana Marques Boabaid', Sandra Hamiro', Leilane Aparecida da Silva', Edson Moleta Colodel' ${ }^{1}$ \& Nadia Aline Bobbi Antoniassi ${ }^{3}$}

\begin{abstract}
Background: Hemangiosarcoma is a malignant endothelial cell-derived neoplasm characterized by an intense cellular proliferation organized in a solid or cavernous pattern. Is characterized by intense cell proliferation, and organized in vascular slits, filled with blood, with fast grow and there is a high recurrence rate. This paper reports a case of multiple hemangiosarcoma in a Rufous-bellied Thrush (Turdus rufiventris).

Case: A free-living Rufous-bellied Thrush (Turdus rufiventris), was attended at the veterinary hospital of the Federal University of Mato Grosso (UFMT) - Cuiabá, presenting prostration and three masses located in the following regions: left periorbital area, left lateral insertion of the beak and distal portion of the left tibia. The masses were blackened colored with an irregular aspect, and the cut surface was multiple cavity, filled with a blackened gelatinous material. The animal died during the surgical procedure and was sent to necropsy. Additionally, special immunohistochemistry staining was used in the tumors sections, with primary anti-S-100, anti-Von Willebrand Factor, anti-desmin, anti-actin, anti-cytokeratin and anti-vimentin. The three masses have rounded shape, multilobuled surface, deep red to blackened color, with skin adhered base, and, when cut, blackened color with multiple cavities filled with red to blackened gelatinous material and compressing the adjacent structures. Microscopically was observed a pronounced multifocal proliferation of the neoplastic endothelial cells, which are organized forming vessels with single cell layer and filled with red blood cells, giving a cavernous aspect to the section. Around these vessels were neoplastic areas with a more solid pattern with cells with elongated nuclei. The masses were partially surrounded by fibrous connective tissue, forming a pseudo capsule. In the immunohistochemical test, a strong positivity for the anti-actin antibody was founded, moderate positivity for anti-desmin, and weak positivity for anti-S-100 and anti- Von Willebrand. The test with anti-vimentin and for cytokeratin antibody was negative.

Discussion: The clinical status of this bird was followed for seven days, but because is a free-living animal there are not much information about the clinical course of the neoplasm. Is known that it's common that animals affected by the hemangiosarcoma have an acute clinical course or asymptomatic, culminating in death, usually associated with hypovolemic shock. The three neoplasms gross aspect described here are compatible with hemangiosarcoma. The masses location were not uncommon although there is a predominance in the intra-coelomic area. In microscopic analysis of the three neoplasm, two histological patterns were observed, both with high cellularity: the cavernous pattern, with exuberant proliferation of blood vessels, and the solid pattern, with few vascular formations. The occurrence of both histological patterns is not uncommon, but the cavernous form being the most frequent. The diagnosis confirmation of hemangiosarcoma was performed by immunohistochemical. The Von Willebrand has low reactivity in avian tissue, as well as the desmin, both with an average to low positivity in this case. The anti-vimentin negative marking in this case generally is observed when the hemangiosarcoma has a more solid histological pattern. The anti-actin antibody is positive for the smooth muscle of the blood vessels, and the anti-S-100 mark nervous tissue, however, although both positive, there are no reports about the specificity of this antibodies to birds tissue. In the author's knowledge, this is the first neoplasm report in a Turdus rufiventris (Rufous-bellied Thrush).
\end{abstract}

Keywords: bird, tumors, tumor sanguine vessel, wild animals. 
S.R. Lima, T.O. Morgado, K.S. Bezerra, et al. 2016. Hemangiosarcoma in a Free-living Rufous-bellied Thrush (Turdus rufiventris).

\section{INTRODUCTION}

Hemangiosarcoma is a malignant neoplasm arising from the endothelial cells of the blood vessels [12]. Is characterized by intense cell proliferation, and organized in vascular slits, filled with blood [18], with fast grow [3] and there is a high recurrence rate [7]. Usually, adult birds of both sexes are affected [18], and it's courses with the clinical manifestation of anemia due to bleeding [7], low immunity, weight loss [7] and coagulation disorder, associated with the hypovolemic shock $[9,12]$. Furthermore, the symptoms varies depending on the mass location and its physiological consequences $[7,8,11]$, and can also manifest with acute [8] or progressive setting [7]. Metastases are common $[5,6]$, occurring in $75 \%$ of cases of hemangiosarcoma [18].

This tumor appears as a soft, multiple cavity and rounded mass $[8,10]$, with invasive growth $[9,18]$, may be associated with bleeding due to disruption of the neoplastic vessels. In birds, it appears as single or multiple mass of 1 to $15 \mathrm{~cm}$ [5], with fast growing and which corresponds to $2.94 \%$ [16] to $14.29 \%$ [5] of the total number of tumors reported in these specie. In a study [5], 5.38\% of the necropsied birds had neoplasms, cholangiosarcoma having the greatest occurrence $(42.86 \%)$ followed by the hemangiosarcoma, cholangioma, lymphoma and carcinoma $(14.28 \%$ each). The primarily affected regions by the hemangiosarcoma in birds, are the paralumbar region, popliteal lymph node [2], cervical region and ventral region of the chest and wing [16].

The aim of this paper is to describe a case of multiple hemangiosarcoma in a Rufous-bellied Thrush (Turdus rufiventris). This is the first neoplasm report in this species.

\section{CASE}

A female, adult, free-living Rufous-bellied Thrush (Turdus rufiventris) was found in the campus of the Federal University of Mato Grosso (UFMT), Cuiabá, Brazil, prostrate, with difficult to fly and also with three masses in the following regions: left periorbital area, left lateral insertion of the beak and the distal portion of the left tibia. The bird was referred for clinical care at the Veterinary Hospital (HOVET) of the university campus.

During the anamnesis was noted a poorly body condition, evidenced by bone palpation of the sternum and decreased muscle mass, paws covered with scaly crusts, feathers came off with handling and three skin masses strongly adhered on skin, with blackened to colored red region. The bird presented a slight difficulty breathing and appeared to feel pain in his left leg, avoiding putting weight on it and lateralizing the body at lay down.

The bird was treated with supportive care. The injured skin was treated with Neodex ${ }^{\circledR} 1$ and Hipoglos $₫ 2$, without improvement. After 70 days the animal underwent surgery for removal of the nodules. Was anesthetized with inhaled isoflurane3, universal vaporizers4, without calibrator, but died during the removal of the masses.

After death the bird was submitted to necropsy. The coelomic cavity, central nervous system and the nodules were collected, fixed in $10 \%$ formalin, processed for histology and stained with hematoxylin and eosin technique (HE) [1]. Additionally, special immunohistochemistry staining was used in the tumors sections, with primary anti-S-100 antibody (rabbit polyclonal antibody, diluted $1 / 200$; regenerative 40 $\min / 100^{\circ} \mathrm{C}, 0.01 \mathrm{M}$ citrate buffer, $\mathrm{pH} 6.0$, the pressure chamber), anti-Von Willebrand Factor (polyclonal rabbit antibody, diluted $1 / 800$, for 1 min recovery / Proteinase $\mathrm{K} 37^{\circ} \mathrm{C}$ with ready-to-use), anti-desmin (clone CD33 monoclonal antibody mouse, 1/300 dilution; 5 min recovery for 2 cycles, Tris-EDTA buffer pH 9.0 at high microwave power), anti-actin (clone 1A 4, mouse monoclonal antibody, dilution 1 / 100; regenerative $40 \mathrm{~min} / 100^{\circ} \mathrm{C}$, with a citrate buffer $\mathrm{pH}$ 6, the pressure chamber), anti-cytokeratin (AE1 / AE3, mouse monoclonal antibody; $1 / 80$ dilution, recovery for $3 \mathrm{~min} / 125^{\circ} \mathrm{C} 0.01 \mathrm{M}$ citrate buffer $\mathrm{pH} 6.0$, chamber pressure) and anti-vimentin (clone V9, mouse monoclonal antibody, dilution $1 / 200$; regenerative 3 $\mathrm{min} / 125^{\circ} \mathrm{C}, 0.01 \mathrm{M}$ citrate buffer, $\mathrm{pH} 6.0$, chamber pressure). All antibodies are from Dako. The blocking reagent for unspecific reactions the $10 \%$ peroxide in methanol for $20 \mathrm{~min}$, blocking of unspecific reactions with Molico ${ }^{\circledR}$ 5\%5 milk for 20 min and developing with red and yellow you like for $20 \mathrm{~min}$ each. Positive controls where used.

On gross examination skin nodules were observed located in the end portion of the left tibia (Figure 1A), a $3.5 \mathrm{~cm}$ in diameter mass, left periorbital (Figure 1B) and the junction between the neck region and left side of the head (Figure 1C) with $1.5 \mathrm{~cm}$. The three masses have rounded shape, multilobuled surface, 
S.R. Lima, T.O. Morgado, K.S. Bezerra, et al. 2016. Hemangiosarcoma in a Free-living Rufous-bellied Thrush (Turdus rufiventris).

Acta Scientiae Veterinariae. 44(Suppl 1): 153.

deep red to blackened color, with skin adhered base, and, when cut, blackened color with multiple cavities filled with red to blackened gelatinous material and compressing the adjacent structures.

Microscopically was observed a pronounced multifocal proliferation of the neoplastic endothelial cells, with intensely basophilic nucleus and scant cytoplasm, which are organized forming vessels with single cell layer and filled with red blood cells, giving a cavernous aspect to the section (Figure 1D). Around these vessels were neoplastic areas with a more solid pattern with cells with elongated nuclei, rather condensed chromatin, with one or two prominent nucleoli and eosinophilic cytoplasm. There was also marked anisocariosis and low mitotic index. The adjacent areas had focally extensive caseous necrosis associated to coccobacilli basophilic aggregates surrounded by infiltration of heterophiles, multinucleated giant cells and marked proliferation of fibrous connective tissue. The masses were partially surrounded by fibrous connective tissue, forming a pseudo capsule.

In the immunohistochemical test, a strong positivity for the anti-actin antibody was founded, moderate positivity for anti-desmin, and weak positivity for anti-S-100 and anti- Von Willebrand. The test with anti-vimentin and for cytokeratin antibody was negative.

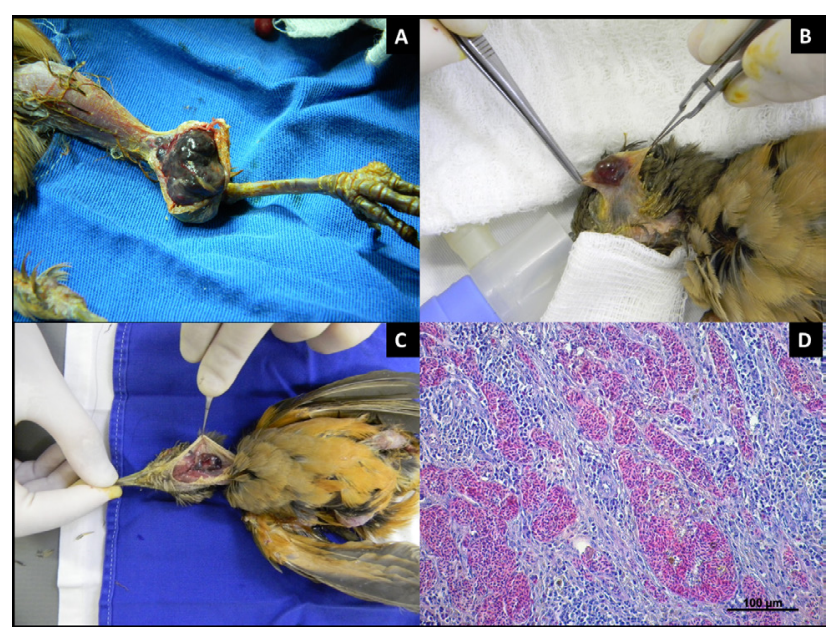

Figura 1. Hemangiosarcoma in Turdus rufiventris. A- Mass observed in the left tibia. B- mass in the left periorbital region. C- Mass of the junction between the neck region and left side of the head. D- photomicrograph showing pronounced multifocal proliferation of the neoplastic endothelial cells, with intensely basophilic nucleus and scant cytoplasm, which are organized forming vessels with single cell layer and filled with red blood cells, giving a cavernous aspect to the section [HE, Obj. 20)].

\section{DISCUSSION}

The clinical status of this bird was followed for seven days, but because is a free-living animal there are not much information about the clinical course of the neoplasm. Is known that it's common that animals affected by the hemangiosarcoma have an acute clinical course [8] or asymptomatic [15], culminating in death $[7,15]$, usually associated with hypovolemic shock [15]. Self-mutilation and tearing feathers, although is no evidence of occurrence in this case, are also reported [15].

The three neoplasms gross aspect described here are compatible with hemangiosarcoma [5]. The masses location that are head, neck and limb, in other words, extra-coelomic regions, were not uncommon although there is a predominance in the intra-coelomic area. In the literature, among the fourteen case reports of hemangiosarcoma in birds, ten were intra-coelomic, of which, three in liver $[5,13,15]$, two in spleen [13], one interclavicle [7], one in the ovary [11], one in the pericardium [8], one in kidney and one in lung [5]. Of the four extra-coelomic, two were in the subcutaneous $[13,17]$, one on the right carpus joint [4] and one in the right orbit region [9]. For emerging from the vascular endothelium, the hemangiosarcoma can be found in any region [7].

During the microscopic analysis of the three neoplasm, 2 histological patterns were observed, both with high cellularity: the cavernous pattern, with exuberant proliferation of blood vessels, and the solid pattern, with few vascular formations. The occurrence of both histological patterns is not uncommon [18] despite the cavernous form being the most frequent $[5,9]$.

Despite the gross lesions and cells morphology suggest a hemangiosarcoma [18], a epithelial origin tissue marker, anti-cytokeratin immunohistochemistry test was performed due to the similarity that hemangiosarcomas may have with carcinomas [7], the result was negative, excluding this hypothesis.

The diagnosis confirmation of hemangiosarcoma was performed by immunohistochemical analysis using anti-actin, anti-desmin, anti-S-100, anti-Von Willebrand and anti-vimentin. Despite the Von Willebrand factor be used to mark endothelial tissue, previous studies demonstrated that this antibody has low reactivity in avian tissue [12], as well as the desmin [15], both with an average to low positivity in this case. The anti-vimentin negative marking in this 
S.R. Lima, T.O. Morgado, K.S. Bezerra, et al. 2016. Hemangiosarcoma in a Free-living Rufous-bellied Thrush (Turdus rufiventris). Acta Scientiae Veterinariae. 44(Suppl 1): 153.

case generally is observed when the hemangiosarcoma has a more solid histological pattern [15]. The antiactin antibody is positive for the smooth muscle of the blood vessels, and the anti-S-100 mark nervous tissue, however, although both positive, there are no reports about the specificity of this antibodies to birds tissue.

By analyzing the results of the antigenantibody interactions on neoplastic cells we observed strong immunohistochemical expression of endothelial tissue, smooth muscle and vascular components, arranged in standard vessels [14], confirming that's a vessels tumor. The diagnosis of hemangiosarcoma was this established, added to the macroscopic and histological features that were consistent with what has been described in the literature $[7,8,11,12,15]$. In the author's knowledge, this is the first neoplasm report in a Turdus rufiventris (Rufous-bellied Thrush).

\section{MANUFACTURERS}

${ }^{1}$ Neo Química Comércio e Industria. São Paulo, SP, Brazil. ${ }^{2}$ Procter \& Gamble do Brasil S.A. São Paulo, SP, Brazil. ${ }^{3}$ Abbott Laboratórios do Brasil Ltda. Rio de Janeiro, RJ, Brazil.

${ }^{4}$ Bonther Equipamentos para Ensino e Pesquisa. Ribeirão Preto, SP, Brazil.

${ }^{5}$ Nestlé Brasil Ltda. Rio de Janeiro, RJ, Brazil.

Declaration of interest. The authors report no conflicts of interest. The authors alone are responsible for the content and writing of the paper.

\section{REFERENCES}

1 Behmer O.A., Tolosa E.M.C. \& Freitas Neto A.G. 1976. Manual de Técnicas para Histologia Normal e Patológica. São Paulo: EDART, 239p.

2 Bodley K.B., Booth R.J., Samuel J. \& Wilkie J.S. 2000. Disseminated haemangiosarcoma in an Eastern barred bandicoot (Perameles gunnii). Australian Veterinary Journal. 78(9): 605-607.

3 Casagrande R.A., Torres L.N., Gomes M.S., Quagglia Neto F., Kanamura C., Kishimoto L. \& Matushima E.R. 2009. Hemangiossarcoma primário intrauterino em um macaco aranha de cara vermelha (Ateles paniscus). Acta Scientiae Veterinariae. 37(1): 59-63.

4 Freeman K.P., Hahn K.A., Adams W.H., Jones M.P. \& Petersen M.G. 1999. Radiation therapy for hemangiosarcoma in a budgerigar. Journal of Avian Medicine and Surgery. 13(1): 40-44.

5 Godoy S.N., Alves V.A.F., Kanamura C.T. \& Matushima E.R. 2009. Principais processos neoplásicos encontrados em psitacídeos mantidos em cativeiro. Pesquisa Veterinária Brasileira. 29(6): 445-451.

6 Guinan J., Fischetti A., Garate A.P. \& Chalhoub S. 2012. Primary peri-aortic hemangiosarcoma in a dog. Canadian Veterinary Journal. 53(11): 1214-1218.

7 Hanley C.S., Wilson G.H., Latimer K.S., Frank P. \& Hernandez-divers S.J. 2005. Interclavicular hemangiosarcoma in a Double Yellow-headed Amazon Parrot (Amazona ochrocephala oratrix). Journal of Avian Medicine and Surgery. 19(2): 130-137.

8 Headley S.A. 2005. Intrathoracic haemangiosarcoma in an ostrich (Struthio camelus). The Veterinary Record. 156(11): 353-354.

9 Marietto-goncalves G.A. \& Grandi F. 2013. Facial Hemangiossarcoma in a Blue-Fronted Amazon Parrot (Amazona aestiva). Acta Veterinaria Brasilica. 7(1): 73-75.

10 Mejía A.F., Gierbolini I., Jacob B. \& Westmoreland S.V. 2009. Pediatric hepatic hemangiosarcoma in a Rhesus Macaque (Macaca mulata). Journal Medicine Primatology. 38(2): 121-124.

11 Mickley K., Buote M., Kiupel M., Graham J. \& Orcutt C. 2009. Ovarian Hemangiosarcoma in an Orange-Winged Amazon Parrot (Amazona amazonica). Journal of Avian Medicine and Surgery. 23(1): 29-35.

12 Nakano Y. \& Une Y. 2012. Hemangiosarcoma with Widespread Mestatasis that Originated on the Matatarsal Pad of a Java Sparrow (Padda oryzivora). Journal Veterinary Medicine Science. 74(5): 621-623.

13 Petrak L.M. \& Gilmore C.E. 1982. Neoplasms. In. Petrak M.L. (Ed). Diseases of Cage and aviary birds. Philadelphia: Lea \& Febiger, pp.606-637.

14 Mitchell R.N. 2013. Vasos sanguíneos. In: Kumar V., Abbas A. \& Aster J.C. (Eds). Robbins: Patologia Básica. 9.ed. Rio de Janeiro: Elsevier Editora Ltda., pp.327-364.

15 Rossi G. 1998. A poorly-differentiated hepatic haemangiosarcoma in an Amazona farinosa parrot. Avian Pathology. 27: 427-430.

16Sinhorini J.A. 2008. Neoplasias em aves domésticas e silvestres mantidas em domicílio: avaliação anatomopatológica 
S.R. Lima, T.O. Morgado, K.S. Bezerra, et al. 2016. Hemangiosarcoma in a Free-living Rufous-bellied Thrush (Turdus rufiventris).

e imunoistoquímica. 131f. São Paulo, SP. Dissertação (Mestrado em Ciências) - Faculdade de Medicina Veterinária e Zootecnia, Universidade de São Paulo.

17 Sledge D.G., Radi Z.A., Miller D.L. \& Lynn B.S. 2006. Subcutaneous Haemangiosarcoma in a Cockatiel (Nymphicus hollandicus). Journal of Veterinary Medicine. 53(6): 293-295.

18 Yamamoto S., Hoshi K., Hirakawa A., Chimura S., Kobayashi M. \& Machida N. 2013. Epidemiological, Clinical and Pathological Features of Primary Cardiac Hemangiosarcoma in Dogs: A Review of 51 Cases. The Journal of Veterinary Medical Science. 75(11): 1433-1441. 